\title{
EudraCT Resubmission Indicator
}

National Cancer Institute

\section{Source}

National Cancer Institute. EudraCT Resubmission Indicator. NCI Thesaurus. Code

C126060.

An indication as to whether the trial being submitted to the EudraCT is a trial that has

been previously submitted to the EudraCT system and withdrawn. 